\title{
Smart city business models - A systematic literature review
}

\author{
Nisha Shetty \\ PhD Researcher \\ University of \\ Wolverhampton \\ Wulfruna Street, England \\ n.shetty@wlv.ac.uk
}

\author{
Suresh Renukappa \\ Senior Lecturer \\ University of \\ Wolverhampton \\ Wulfruna Street, England \\ suresh.renukappa@wlv.ac.uk
}

\author{
Subashini Suresh \\ Reader \\ University of \\ Wolverhampton \\ Wulfruna Street, England \\ s.subashini@wlv.ac.uk
}

\author{
Khaled Algahtani \\ Researcher \\ University of \\ Wolverhampton \\ Wulfruna Street, England \\ k.m.a2@wlv.ac.uk
}

\begin{abstract}
Business models have routed its way through smart cities. This, being an important phenomenon for an organisations success the concept has not been defined accurately. Literature review defines this as fuzzy and vague concept despite its importance to organisations is tremendous. This paper advances our understanding of the business model concept by reviewing the different types of business models and business model definitions following a systematic literature review approach. The paper progresses with a comparison between the businesses models developed for the smart cities domain. The paper seeks to address the question - How are smart cities going to generate economic value?
\end{abstract} concept

Keywords: Smart city, business models, business model

\section{INTRODUCTION}

Smart cities are defined as the paradigm of progress to the new world. Countries are building cities with social, economical and sustainable aspects to enhance the quality of life for the citizens. Along with the incorporation of ICT smart cities have to prioritize on the protection and security of its citizens, financial independence and social infrastructure. Smart cities are moving towards shaping the future of the world. The prime concern is the huge amount of money required to build smart cities. An estimated of \$41trillion is being spent on building smart infrastructure by cities around the world [13]. The UN's 2030 agenda is to build "sustainable cities and communities" which has been supported by 193 countries. These cities are designed to be more inclusive, safe, resilient and environmentally-friendly. An investment in a smart city looks at cities characteristics, the requirements of capital for different investments and the process of decision making [14].

These technological challenges develop ways of creating values crisis in cities and hence the need for business models [3]. Business models are the drivers of a firm's objective and help in conceptualizing the way business is done [6]. Literature shows the emerging combination of the two buzzing areas of smart cities and business models. The business model concept is applied to the area of smart cities which help in gaining the knowledge on business cases and the related factors.
This paper is conceptualised with an approach to deliver the economic value of business models to smart cities. It is built up on literature review collected from systematic sample of papers related to smart cities and business models. String of keywords used in combination "smart cities", "business model". Further the research seeks to address the economic value of business models in smart cities.

Analysing the literature on business models and smart cities on the database Scopus from 1998-2019 provided with the following graphs below:

The search term used on the Scopus database "business model" and "smart cities" and the combination of the terms. The blue line in the graph show the number of articles in business model and red line shows the number of articles in smart cities. The columns in green shows the result of number articles resulted in the search database with combination of the two emerging concepts business model and smart cities.

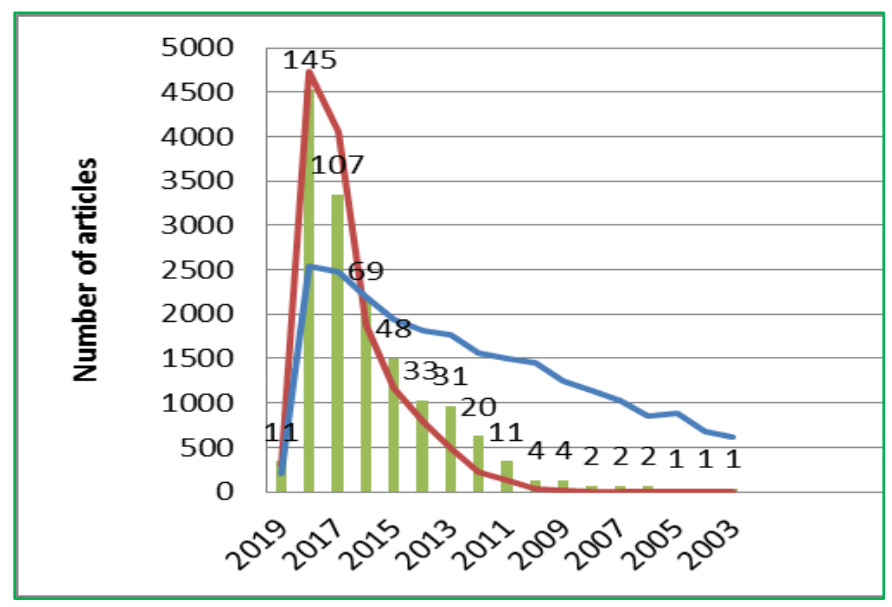

Figure 1 Analysis of number of articles

All the papers identified in the search were reviewed based on criteria of the keywords and the presentation of the concepts related to business model and smart cities. The abstract for the selected papers and peer-reviewed articles were further reviewed in the scientific database Scopus. 


\section{BUSINESS MODEL DEFINITION}

The term business model has been defined in various scenarios by scholars and organisations (See Table 1). It provides value chain thinking, networked approach and sharing economy to the organisations. Literature provides a host of definition to the term business model, derived based on different strategies.

TABle 1 Business Model Definitions

\begin{tabular}{|c|c|c|}
\hline Author & Business Model Definition & $\begin{array}{c}\text { Basis of the } \\
\text { Definition }\end{array}$ \\
\hline $\begin{array}{l}\text { Timmers, } \\
1998\end{array}$ & $\begin{array}{l}\text { The business model is "an } \\
\text { architecture of the product, service } \\
\text { and information flows, including a } \\
\text { description of the various business } \\
\text { actors and their roles; a description } \\
\text { of the potential benefits for the } \\
\text { various business actors; a } \\
\text { description of the sources of } \\
\text { revenues" (p. 4) }\end{array}$ & $\begin{array}{l}\text { Architecture, } \\
\text { revenue }\end{array}$ \\
\hline $\begin{array}{l}\text { Rappa, } \\
2000\end{array}$ & $\begin{array}{l}\text { A business model is the method of } \\
\text { doing business by which a company } \\
\text { can sustain itself, that is, generate } \\
\text { revenue. The business model spells } \\
\text { out how a company makes money } \\
\text { by specifying where it is positioned } \\
\text { in the value chain. }\end{array}$ & Revenue \\
\hline $\begin{array}{l}\text { Magretta, } \\
2002\end{array}$ & $\begin{array}{l}\text { "[Business models] are, at heart, } \\
\text { stories-stories that explain how } \\
\text { enterprises work [and answer the } \\
\text { following questions,] Who is the } \\
\text { customer? And what does the } \\
\text { customer value? It also answers the } \\
\text { fundamental question every } \\
\text { manager must ask: How do we } \\
\text { make money in this business? What } \\
\text { is the underlying economic logic } \\
\text { that explains how we can deliver } \\
\text { value to the customers at an } \\
\text { appropriate cost?" (p. 87) }\end{array}$ & $\begin{array}{l}\text { Customer } \\
\text { relationships }\end{array}$ \\
\hline $\begin{array}{l}\text { Leem et al. } \\
2004\end{array}$ & $\begin{array}{l}\text { A set of strategies for corporate } \\
\text { establishment and management } \\
\text { including a revenue model, high- } \\
\text { level business processes, and } \\
\text { alliances. }\end{array}$ & Revenue \\
\hline $\begin{array}{l}\text { Kallio et al. } \\
2006\end{array}$ & $\begin{array}{l}\text { The means by which a firm is able } \\
\text { to create value by coordinating the } \\
\text { flow of information, goods and } \\
\text { services among the various industry } \\
\text { participants it comes in contact with } \\
\text { including customers, partners within } \\
\text { the value chain, competitors and the } \\
\text { government. }\end{array}$ & $\begin{array}{l}\text { Business } \\
\text { marketing } \\
\text { strategies }\end{array}$ \\
\hline $\begin{array}{l}\text { Richardson, } \\
2008\end{array}$ & $\begin{array}{l}\text { A business model is "a conceptual } \\
\text { framework that helps to link the } \\
\text { firm's strategy, or theory of how to } \\
\text { compete, to its activities, or } \\
\text { execution of the strategy. The } \\
\text { business model framework can help }\end{array}$ & $\begin{array}{l}\text { Business } \\
\text { marketing } \\
\text { strategies }\end{array}$ \\
\hline
\end{tabular}

\begin{tabular}{|c|c|c|}
\hline & $\begin{array}{l}\text { to think strategically about the } \\
\text { details of the way the firm does } \\
\text { business." (p. 135) "The three major } \\
\text { components of the framework - } \\
\text { the value proposition, the value } \\
\text { creation and delivery system, and } \\
\text { value capture - reflect the logic of } \\
\text { strategic thinking about value. The } \\
\text { essence of strategy is to create } \\
\text { superior value for customers and } \\
\text { capture a greater amount of that } \\
\text { value than competitors." (p. 138) }\end{array}$ & \\
\hline $\begin{array}{l}\text { Teece, } \\
2010\end{array}$ & $\begin{array}{l}\text { "A business model articulates the } \\
\text { logic, the data and other evidence } \\
\text { that support a value proposition for } \\
\text { the customer, and a viable structure } \\
\text { of revenues and costs for the } \\
\text { enterprise delivering that value" (p. } \\
\text { 179). }\end{array}$ & $\begin{array}{l}\text { Revenue } \\
\text { Business } \\
\text { marketing } \\
\text { strategies }\end{array}$ \\
\hline $\begin{array}{l}\text { Wirtz et al., } \\
2016\end{array}$ & $\begin{array}{l}\text { "A business model is a simplified } \\
\text { and aggregated representation of the } \\
\text { relevant activities of a company. It } \\
\text { describes how marketable } \\
\text { information, products and/or } \\
\text { services are generated by means of } \\
\text { a company's value-added } \\
\text { component. In addition to the } \\
\text { architecture of value creation, } \\
\text { strategic as well as customer and } \\
\text { market components are taken into } \\
\text { consideration, in order to achieve } \\
\text { the superordinate goal of } \\
\text { generating, or rather, securing the } \\
\text { competitive advantage. To fulfil this } \\
\text { latter purpose, a current business } \\
\text { model should always be critically } \\
\text { regarded from a dynamic } \\
\text { perspective, thus within the } \\
\text { consciousness that there may be the } \\
\text { need for business model evolution } \\
\text { or business model innovation, due } \\
\text { to internal or external changes over } \\
\text { time." (p.41) }\end{array}$ & $\begin{array}{l}\text { Architecture, } \\
\text { Revenue }\end{array}$ \\
\hline
\end{tabular}

With the concept being widely discussed, an appropriate definition for business model has not been derived. For any organisation, be it a multi-national company or a new venture the business model has to create, deliver and capture values which are social, economic and cultural [1]. The basic elements a business model concept follows are product, customer interface, infrastructure management and financial aspects [4]. Therefore in the context of this research study a business model could be defined as "an architectural design which strategizes on governance, customer relationships, business marketing and revenue for a positive quality of life for the citizens".

\section{RESEARCH METHODOLOGY}

The paper has followed a systematic literature review approach, developed by Webster and Watson in [3]. Firstly, 
the scope of review has been defined and the emerging topics conceptualized with definitions, literature search, analysing and synthesising literature progressing with a research agenda. With topics of research based on regions, the topic concepts were derived. Authors described the different types of business model based on value proposition. Different types of business models were compared with case studies and business model pattern. The research further helped with identification of keywords for literature search. Relevant papers were searched in the scientific database Scopus. Scopus is the largest database of peer-reviewed literature. It has comprehensive publications in the field of science, technology, management, arts and humanities. The initial search phase was extended from "business model" and "smart cities" to terms related to different kinds of business models that could be developed for smart cities agenda. Keywords "business model", "sustainable business model", "business model innovation" and "smart cities" were the keywords searched to conduct the research. Title, abstract and keywords were searched for the above terms. Peerreviewed papers in English language with the above search terms were recorded for the literature review. Fifteen papers from the above-mentioned criterion were selected for review of literature.

\section{FINDINGS AND DISCUSSION}

Research studies have shown that smart city domain has evolved into different business models. The proposed model requires the process of improved urbanisation, reduce problems regarding security and food safety, urban crime, road safety etc.

Business models are classified into different patterns like unbundling business models, long tail business model, multisided platform and free business model grouped into webbased, e-commerce and network ownership [1]. Literature reveals that different patterns of business models are utilised by smart cities based on the examined cases for cities in different regions. Business models provide significant revenue to smart city owners through internal efficiency, money, city infrastructure or value integration [1].

Sustainable business models are designed with sustainable ambitions for an organisations transformation to a more economic system and the integration of sustainability considerations [5]. As defined by [5] "business models that incorporate pro-active multi-stakeholder management, the creation of monetary and non-monetary value for a broad range of stakeholders and hold a long-term perspective". The focus of this kind of model is based on two elements customer and economic value.

Business model innovation describes the design process for giving birth to a fairly new business model on the market, which is accompanied by an adjustment of the value proposition and/or the value constellation and aims at generating or securing a sustainable competitive advantage [3]. As defined by [5], business model innovation is "the conceptualisation and implementation of new business models. This can compromise the development of entirely new business models, the diversification into additional business models the acquisition of new business models, or the transformation from one business model to another. The transformation can affect the entire business model or individual or a combination of its value proposition, value creation and deliver value capture elements, the interrelations between the elements, and the value network". The above definitions provided gives a general view of the importance a business model innovation provided through value proposition and the inclusion of product, service and supply chain innovation.

Circular Business model is a reduce, retain, recycle model which strives to employ less resources, extends life and provides a full life cycle. The circular business model provides sustainable value, pro-active multi-stakeholder management, long-term perspective, intensifying and dematerializing resource loops which provide solutions for sustainability and circular economy [5].

Strategizing cities with management and marketing policies is the important aspect leaders need to work on. Smartness of city is based on six elements smart people, smart governance, smart mobility, smart environment, smart living and smart economy. A SMART model designed by [2] which stands for Strategy, Multidisciplinary, Appropriation, Roadmap and Technology. The SMART model directs the leaders on the starting point and the future steps to follow. Though business models have not been used in the smart city context as the requirement for value proposition or economic benefit, it has been used to improve the positivity of citizens.

Nine building blocks of a successful business model to strengthen the services, customer interface, infrastructure management and financial aspects of a smart city are developed by [3]. Value proposition gives an overview of the services provided by a company. In a customer interface: the target customer describes the segments to offer value to, distribution channel helps to get in touch with the customer and relationship builds the link between the company and customer.

Focusing on the strengthening of the infrastructure, value proposition, core competency and partner network are the most important factors to be considered for the execution of an efficient business model. Financial aspects such as cost structure and revenue model sums up the monetary consequences of a business model. A business model needs to be strategized by focusing on building long-term relationships, government commitment, future vision, taking standards based approach, creating investment opportunities and engaging citizens with the use of technology.

These business models scouted from literature provide an insight into the development in the area of smart cities and business models. Building smart cities with a planned sustainable and innovative business model would result in a starting point to develop opportunities for countries. Policy 
makers could provide an analysis and corroborate business model-friendly laws and supporting policies. Cities could be made smarter with an effective sustainable and innovative business model focusing on leadership, process, people, technology and legal aspects that can create value for the society, capture the value produced and strategize the financial investments.

\section{CONCLUSION}

Analysis of different business model stereotypes and archetypes for smart cities has developed an intangible agenda of research at the intersection of business models and smart cities. The research paper focused on the research question on delivering economic value through business models for smart cities. Literature findings on smart city business models showed different business models that could be developed for the smart city agenda. Business models designed on different patterns, sustainable business model, business model innovation, circular business model, the SMART model and theoretical framework business model was discussed to provide an overview of the economic factor and value proposition on smart cities.

The paper provides a future research direction on business models that could focus on the regional specific and subject specific areas of smart cities. As business innovation approaches focusing on industrialised countries and developing countries are the focal points in the smart cities agenda.

\section{REFERENCES}

[1] Anthopoulos, L. and Fitsilis, P. (2015) Understanding Smart City Business Models: A Comparison ACM.

[2] Ben Letaifa, S. (2015) 'How to strategize smart cities: Revealing the SMART model', Journal of Business Research, 68(7), $\quad$ pp. 1414-1419. doi: 10.1016/j.jbusres.2015.01.024.

[3] Díaz-Díaz, R., Muñoz, L. and Pérez-González, D. (2017) 'Business model analysis of public services operating in the smart city ecosystem: The case of SmartSantander', Future Generation Computer Systems; Future Generation Computer Systems, 76, pp. 198-214. doi: 10.1016/j.future.2017.01.032.

[4] Engelken, M., Römer, B., Drescher, M., Welpe, I.M. and Picot, A. (2016) 'Comparing drivers, barriers, and opportunities of business models for renewable energies: A review', Renewable and Sustainable Energy Reviews, 60, pp. 795-809. doi: 10.1016/j.rser.2015.12.163.

[5] Geissdoerfer, M., Vladimirova, D. and Evans, S. (2018) 'Sustainable business model innovation: A review', Journal of Cleaner Production; Journal of Cleaner Production, 198, pp. 401-416. doi: 10.1016/j.jclepro.2018.06.240.

[6] Yip, A.W.H. and Bocken, N.M.P. (2018) 'Sustainable business model archetypes for the banking industry', Journal of Cleaner Production; Journal of Cleaner Production, 174, pp. 150-169. doi: 10.1016/j.jclepro.2017.10.190.

[7] Mostaghel Rana and Oghazi Pejvak (2017) "What are Circular Business Models (CBM)?", Innovation Shetty,N., Renukappa, S., and Suresh, S., Algahtani, K (2019) "Smart city business models - A systematic literature review." 3rd International Conference on Smart Grid and Smart Cities 2019, June 25-28, 2019 | University of California, Berkeley, USA
Managemnt.se,website:http://www.innovationmanagement.se/ 2017/11/16/what-are-circular-business-models-cbm/

[8] Thangavel C., Sudhaman P. (2018) A Business Model for Digital Services for Smart Cities in India. In: Mahmood Z. (eds) Smart Cities. Computer Communications and Networks. Springer, pp 263-280

[9] Bleus, H., Crutzen, N. and Smart, C.I. (2018) Business Model and Smart City, a literature review.

[10] Schiavone, F., Paolone, F. and Mancini, D. (2018) Business model innovation for urban smartization Elsevier Inc.

[11] Casadesus-Masanell, R. and Ricart, J.E. (2011) 'How to design a winning business model: smart companies' business models generate cycles that, over time, make them operate more effectively.(Spotlight on Business Model Innovation)', Harvard business review, 89(1), pp. 100.

[12] Khomsi, M. (2016) 'The Smart City Ecosystem as an Innovation Model: Lessons from Montreal', Technology Innovation Management Review, 6(11), pp. 26-31. doi: 10.22215/timreview/1032.

[13] Galati R.(2018) "Funding a Smart City: From Concept to Actuality", Smart cities, applications, Technologies, standards and driving factors, Spring International Publishing pp 239

[14] Macomber J. (2018) "The smart way to build smart cities" ForbesWebsite:<https://www.forbes.com/sites/hbsworkingkn owledge/2018/04/04/the-smart-way-to-build-smartcities/\#5edd5f897b19>

[15] GSMA(2016) "Keys to the Smart City", GSMA Website: <https://www.gsma.com/iot/smart-cities/>

[16] Timmers P. (1998) "Business models for electronic markets" Electron. Market., 8 , pp. 3-8

[17] Rappa, M.A. (2004) 'The utility business model and the future of computing services', IBM Systems Journal, 43(1), pp. 32-42. doi: $10.1147 / \mathrm{sj} .431 .0032$.

[18] Magretta, J. (2002) 'Why Business Models Matter', Why Business Models Matter,

[19] Richardson, J. (2008) 'The business model: An integrative framework for strategy execution', Strategic Change, 17(5-6), pp. 133-144.

[20] Teece, D.J. (2010) 'Business models, business strategy and innovation', Long range planning, 43(2-3), pp. 172-194. doi: 10.1016/j.lrp.2009.07.003.

[21] Leem C.S., Suh H.S., Kim D.S. (2004) 'A classification of mobile business models and its applications' Industrial Management \& Data Systems 104(1):pp 78-87 DOI: $10.1108 / 02635570410514115$

[22] Kallio J, Tinnilia M, Tseng A (2006) 'An international comparison of operator-driven business models' Business Process Management Journal 12(3): pp 281-298 DOI: $10.1108 / 14637150610667962$

Wirtz, B.W., Pistoia, A., Ullrich, S. and Göttel, V. (2016) 'Business Models: Origin, Development and Future Research Perspectives', Long range planning, 49(1), pp. 36-54. doi: 10.1016/j.lrp.2015.04.001. 
Shetty,N., Renukappa, S., and Suresh, S., Algahtani, K (2019) "Smart city business models - A systematic literature review." 3rd International Conference on Smart Grid and Smart Cities 2019, June 25-28, 2019 | University of California, Berkeley, USA 